\title{
Product Characteristics, Market Competitive Strategies, and SMEs Performance: Testing Their Relationships
}

\author{
Dikdik HARJADI ${ }^{1}$, Ahyar YUNIAWAN ${ }^{2}$, Agus ABDURRAHMAN ${ }^{3}$, Radyan DANANJOYO ${ }^{4}$, \\ EIdes Willy FILATROVI ${ }^{5}$, Iqbal ARRANIRI ${ }^{6}$
}

Received: July 30, 2020 Revised: August 26, 2020 Accepted: September 04, 2020

\begin{abstract}
COVID-19 pandemic has made the economy in Indonesia sluggish, especially Small and Medium Enterprises (SMEs). Simultaneously, the SMEs existence in Indonesia is fundamental and considered important by the government since it is able to assist numerous laborers and become an income source for the lower and middle classes of the community. The productivity of SME in a region will undeniably influence the availability of job and, of course, reduce the number of unemployed. Therefore, in this study, the researchers looked at how to improve SMEs performance to continue to exist amid the COVID-19 pandemic, by identifying the relationships between product characteristics, market competitive strategies, and the performance of SMEs. The research was done on SMEs in West Java, Indonesia. The example employed was Batik SMEs in Cirebon with at least 10 years in existence, and the total number of these SMEs was 165 . As the basis of a quantitative approach, this study employed survey instruments by distributing a questionnaire. In analyzing the data, it utilized the structural equation modeling (SEM). The result showed a significant relationship between Product Characteristics, Market Competitive Strategy, and Price and Product Success Rate on SMEs Performance. This study's findings contribute to the SMEs performance literature.
\end{abstract}

Keywords: Product Characteristics, Market Competitive Strategies, SMEs Performance

JEL Classification Code: L1, P23, P42

\section{Introduction}

Indonesia SMEs' existence is vital and is considered important by the government since it is able to help numerous

${ }^{1}$ First Author. Business and Economic Faculty, Universitas Kuningan, Kuningan, Indonesia

${ }^{2}$ Business and Economic Faculty, Universitas Diponegoro, Semarang, Indonesia

${ }^{3}$ Business and Economic Faculty, Universitas Islam Indonesia, Yogyakarta, Indonesia

${ }^{4}$ Corresponding Author. Business and Economics Faculty, Universitas Muhammadiyah Yogyakarta, Indonesia [Postal Address: Jl.

Brawijaya, Tamantirto, Kec. Kasihan, Yogyakarta, 55183, Indonesia] Email: radyan.dananjoyo@umy.ac.id

${ }^{5}$ Sekolah Tinggi IImu Ekonomi, Bank BPD Jateng, Semarang, Indonesia

${ }^{6}$ Business and Economic Faculty, Universitas Kuningan, Kuningan, Indonesia

(C) Copyright: The Author(s)

This is an Open Access article distributed under the terms of the Creative Commons Attribution Non-Commercial License (https://creativecommons.org/licenses/by-nc/4.0/) which permits unrestricted non-commercial use, distribution, and reproduction in any medium, provided the original work is properly cited. workers and turn into an income source for the community's lower and middle classes. The productivity of SME in a region will certainly influence the availability of jobs and will surely, reduce the number of unemployed people (Yuniawan, Harjadi, Filatrovi, Dananjoyo, \& Arraniri, 2020). Total number of SMEs in 2016 was verified as many as 45 million business units. Thus, most of economic actors were small and medium businesses. Besides, this sector absorbed 79 million people from 100 million Indonesian workforce. Hence, numerous attempts are required to be made to expand small businesses in Indonesia to be better. SMEs that can survive in a long period are industries that can anticipate changes in every era.

Competition in the business world is becoming increasingly tight, which pushes the SMEs to find the right strategy in marketing their products (Becker, Lee, \& Nobre, 2018). The interest to purchase is derived from thought processes and learnings that shapes an urge to purchase. This enthusiasm to buy makes a motivation that continues being recorded in the psyche of the consumers. It turns into an exceptionally powerful urge that toward the end, when a consumer has to meet his necessitates, he will actually purchase the things which was registered in his mind. 
Every business actor has a goal to realize growth and survival in the long run. To achieve these objectives, the business actor must have the ability to analyze the business environment through management strategies accurately (Muafi, 2020). Globalization requires companies to compete globally. In order to compete at the global level, companies require right strategies. A strategy might be characterized as an incorporated and environment-focused approach to realize the mission of the organization. Therefore, strategic management is the ongoing procedure of seeking a positive competitive fit between the organization and its dynamic condition.

The competition that takes place among businesses is no longer only related to the quality of products and product excellence but it is also about the "price war". To deal with the tough market competition, apart from relying on the quality of its products, SMEs in Cirebon continue to develop creativity and innovation in order to provide high quality products with excellence in each of the products they sell in the market, so they can still lead the SME batik market.

During the COVID-19 pandemic, SMEs in the city of Cirebon experienced decline in sales. Many businesspeople complained about this situation because many batik products that had already been produced could not penetrate the market because there was no purchasing power in the community. There has been a drastic decrease in SME Batik market was due to the current COVID-19 pandemic, where all economic activities, especially batik SMEs in Cirebon, have been paralyzed and are experiencing a decline.

The problem in this research is the decline in the market share of batik sales during the COVID-19 pandemic. The decline cannot be allowed to continue, so it is necessary to re-identify all the resources that can form a competitive advantage, especially related to product innovation. Research conducted by Henard and Szymanski (2001) strengthens the causal relationship in sequence between product success with product characteristics, business strategy characteristics, and product development characteristics. Based on the description of the problems above, the researcher conducted a research about the effect of price, product characteristics, and market competitive strategies on the level of product success on SMEs performance.

\section{Literature Review}

\subsection{Small-Medium Enterprises}

SMEs are industries that are able to withstand shockwaves, which was demonstrated in the midst of monetary crisis where some organizations with huge scope fell, yet SMEs were able to endure and were termed as the savior belt from the effects of the crisis (Yuniawan, Harjadi, Filatrovi, Dananjoyo, \& Arraniri, 2020). This type of business classification refers to the Republic of Indonesia's Presidential Decree No. 99 of 1998, or Decree of the Minister of Finance No.40/KMK.06/2003 dated January 29, 2003, of the Ministry of State Minister for Cooperatives and Small and Medium Enterprises. However, basically, all of seem to have the same understanding as far as definition of micro business is concerned, namely: "Small-scale people's economic activities with business sectors are predominantly small business activities which needs to be protected from unfair business competition."

\subsection{Product Characteristics}

In creating a new product, product characteristics are influenced by three indicators: product excellence, products according to the needs of the buyer, and the product following the development of technology (Henard \& Szymanski, 2001). In all cases, businesses generate the knowledge of the market related to competitors and customers to enhance the superiority of new products. The emergence of a trend in this new product development has not come all of a sudden, but it coincides with the current wave of growth in marketing which is centered on the competence in understanding the market conditions.

Glazer (1991) in the research on market knowledge and its strategic implications considered market knowledge competence as a vital resource of an association. Prahalad and Hamel (1990) and Sinkula (1994) expected market knowledge competence as the main competency of businesses. Cooper (1992), Gupta, Raj, \& Wilemon (1985) used market knowledge competencies to improve the excellence of new products.

In the theory of Neoclassical, for production, the most critical resources are land, labor, and capital. Nevertheless, as knowledge and information substitute energy and goods as the essential production sources (Bell, 1976), the theory of Neoclassical turns out to be less viable and is replaced by the theory of company based on resource (Conner, 1991). It develops resources' types (from land, workers, and cars) to involve intangibles as competencies in organizational culture, market knowledge, as well as management skills. Market knowledge competencies' disclosure as "higher level" resources and, when used, may result in competitive advantage. Even though the competencies' view in market knowledge resources shows an increase in the development of theory, the operational meaning of this idea is essential for empirical testing since the term "resources" itself is an umbrella that encompasses tangible and intangible assets and is expected to pass on the property competencies of market knowledge itself.

Furthermore, in part of investigations concerning key issues in product innovation, Doyle and Wong (1998) noted the company's competitiveness in developing new products 
in the process using knowledge of competitors and customers and incorporating these customers with technology. New products launches for customers are expected to have unique and superior product qualities that are also in accordance with the buyer's expectations from the product. The product price is expected to be affordable to the customer, and product innovation should follow the current and future technological developments.

\subsection{Market Competency Strategy}

Companies must adapt and innovate continuously. Because the needs and expectations of customers continue to develop over time, it must, therefore, be followed and responded to by continuously producing high-quality products and services to transform market needs into competitive market strategies. Considering the significance of market knowledge competence is an occurrence of the development of current theory. Disclosure of market knowledge competencies as "higher level" resources and, when used, may result in competitive benefit (Hunt and Morgan, 1995). Even though the competencies' view in market knowledge resources shows an increase in the development of theory, the operational meaning of this idea is essential for empirical testing since the term "resources" itself is an umbrella that encompasses tangible and intangible assets and is expected to pass on the property competencies of market knowledge itself. Market knowledge and market knowledge competencies are two related concepts but separated. Li and Calantone (1998) defined market knowledge as planned information, meaning the results of a systematic process (as contradicted to random retrieval), and structured, indicating that it has a beneficial denotation. $\mathrm{Li}$ and Calantone (1998) defined market knowledge competence as a process that drives and integrates market knowledge.

At this point, there is a series of activities in view of the market competition. Market competence is a complex set of skills and shared learning that is practiced in organizational processes. In their research on the company's core competencies, Prahalad and Hamel (1990), Li and Calantone (1998) noted that company competencies in developing new products is the process which uses the knowledge of competitors and customers and integrates that knowledge with technology. As a series of process, market knowledge competencies exhibit a number of characteristics, including the ability which safeguards against imitation, this is made possible as the process of acquiring market knowledge is ingrained in organizational thought activities and cannot be directly observed from outside (Prahalad and Hamel, 1990, Li and Calantone, 1998), which recognizes company's processes in developing new products by using knowledge of competitors and customers and consolidating that knowledge with technology.
$\mathrm{Li}$ and Calantone (1998) recommended market knowledge and competition awareness for the development of new products that consists of three processes: (1) the process of customer knowledge, (2) the process of competitor knowledge, and (3) research and development of interface marketing. The customer knowledge process alludes to knowledge of a set of behavioral activities of customers which will have a bearing on the current and future needs of a new product. The knowledge competency process consists of a set of behavioral activities that will help in acquiring knowledge regarding competitors' strategies and products. The research and development marketing interface refers to the process by which the marketing research and development operates to communicate and collaborate. Based on Nerver and Slater's (1990) statement, the market competency strategy as a competitive strategy consists of three behavioral elements: the orientation of customer, the orientation of competitor, and the coordination of interfunctional. Thus, the orientation of the customer and the orientation of the competitor take account of all activities involved in obtaining information concerning competitors and customers in the target market which is related to the business. Whereas, functional coordination is constructed on the information of competitor and customer, and consists of coordinated business ventures.

\subsection{Price}

As stated by Kotler and Armstrong (2006), price is the measure of cash paid for a service or product or the measure of significant worth that customers trade for the benefits of possessing or utilizing a service or a product. The market price of a product affects wages, rent, interest, and profit. It means product prices affect the factors of production costs (capital, labor, land, and entrepreneurship). Therefore, the definition of prices is a basic measure of an economic system because prices affect the allocation of production factors. Besides, prices can also be defined as the amount of money needed to obtain several combinations of a product and the accompanying services.

\subsection{Product Success Rate}

The innovation of product is progressively esteemed as a key part of continuous achievement in the business process. In their research, Henard and Szymanski (2001) said that product excellence, market potential, meeting customer needs, pre-development of job skills, and resource use, in general, are the most common factors that have a significant impact on the performance of new products. According to Samu, Krishnan, \& Smith (1999), the attributes or characteristics of new products sold in the market will determine the level of success of these products. The 
consumer's decision to repurchase the product is a form of success for the new product. The components, attributes, and characteristics of the product are essential things that must be considered to improve its market performance. One indication of a product's success or failure is consumer buying interest (how much is someone's interest to buy a product). It can be said that this interest will give birth to the frequency of purchase or repurchase; therefore, the dimension of purchase interest is the amount of interest or how likely the purchase is going to happen (Mittal, 2002).

\subsection{Business Performance}

According to Jeaning and Beaver (1997), business performance is a measure of the development and success of small and medium and large companies. Measurements of investment returns, growth, volume, profits, and labor in general companies are carried out to determine the company's performance. The measurement of performance is complex and a major encounter for researchers, as indicated by Beal (2000), as a result of the construct of multidimensional performance, and along these lines, the performance of measurement with only one dimension of measurement could not give a far reaching comprehension. The measurement of performance, according to Bhargava et al. (1994), should use or integrate multiple measures. Beal (2000) suggested no concurrence on the most suitable measurement of performance, and the objective performance measures that have been utilized in numerous examinations are still inadequate. For example, the size of ROI (Return on Investment) has shortcomings because there are various methods of measuring depreciation, inventory, and fixed cost values.

Furthermore, Beal (2000) argues that accounting and financial-based organizational performance measures have flaws because of the variety of accounting methods, also due to the tendency of manipulation of numbers from management, the measurements become invalid. To compensate for the unavailability of objective performance data in a study, it is reasonable to utilize subjective measures on the basis of the perceptions of managers. Zahra and Das (1993) prove that subjective performance measures have a high level of reliability and validity. Besides, Voss and Voss (2000) showed that there was a close relationship between subjective performance measures and objective performance measures.

The performance of business is an aspect generally employed to calculate the influence of strategies adopted by the company. Specifically, the performance of an outlet is an idea to evaluate the business activities' achievements done by an outlet or agent. However, Keats and Hitt (1988) stated that the concept of performance is challenging both in its measurement and definition. Beal (2000) stated that the measurement of performance is complex and a major encounter for researchers. It is a major encounter as a result of the construct of multidimensional performance, and along these lines, the performance of measurement with only one dimension could not give a far reaching comprehension. High performance of business is influenced by the superiority of the company's products with the existing level of competition. Kim and Mauborgne (2005) suggested that to obtain high performance; companies need to win the competition in the future, a successful organization is established not just because of fighting with competitors but by creating a blue ocean strategy from a new space unmatched in a market. The four indicators: profit growth, customer growth, market growth, and sales growth, are the variables of business performance.

\section{Hypotheses Development}

\subsection{The Impact of Product Characteristics on Product Success Rate}

The company can maintain product superiority or better standards with unique features (Delene, Meloche, \& Hodskins, 1997). Li and Calantone (1998) said that product success is partly related to the uniqueness, and the presence of the product is an advantage over other products. Compared to other products, it is one of the factors that determine the success or failure of the product. Besides, it can also be said that the management of consumer knowledge could be used as one of the elements that decide the organization to expand the new products' success, as stated by Hamel and Prahalad (1990). In the research conducted by Cooper (1992), several things about the research agenda are essential to do. It is where research needs to be done to examine product marketing performance and the factors that influence it (Cooper, 1992). Meanwhile, in the research conducted by Song and Parry (1997), to find out the success of new products, it can be seen from the product's market performance. Then, in research conducted by Delene, Meloche, and Hodskins (1997), it examines the advantages of competitive new products, stating the need for further research on product strategies that improve market performance.

H1: There is a positive influence of product characteristics on the level of product success

\subsection{The Impact of Market Competitive Strategies on the Level of Product Success}

Li and Calantone (1998) recommended market knowledge and competition in the development of new products that consists of three processes: (1) the process of customer 
knowledge, (2) the process of competitor knowledge, and (3) research and development of interface marketing. The customer knowledge process alludes to a set of behavioral activities that affects the new product's current and potential needs. The knowledge competency process contains a set of behavioral activities that helps in acquiring knowledge regarding competitors' strategies and products. The research and development marketing interface refers to the process by which the marketing research and development operates to communicate and collaborate.

Based on the statement of Lestari, Leon, Widyastuti, Brabo, and Putra (2020), and Nerver and Slater (1990), the strategy of market competence as a competitive strategy consists of three behavioral elements: the orientation of customer, the orientation of competitor, and the coordination of inter-functional activities. Thus, the orientation of the customer and the orientation of competitors take account of all activities involved in obtaining information concerning competitors and customers in the target market. Whereas, functional coordination is constructed on the information of competitor and customer, and consists of coordinated business ventures. Strictly speaking, Kholi, Jaworski, and Sahay (2000) defined competitive market strategies into three types namely: customer focus, coordinate marketing, and profitability, because these three things are closely related to the organization's decision-making process based on information obtained and have undergone a process of unification of the values of the behavior that is embraced (culture) owned by the company. Jaworski, Kohli, and Sahay (2000) stated that customer needs and expectations continue to develop over time, and therefore must be followed and responded to by producing high-quality products and services continuously to transform market needs into competitive market strategies.

H2: There is a positive influence of market competitive strategies on the level of product success

\subsection{The Impact of Prices on Product Success Rates}

For some types of products, consumers prefer to buy products at lower prices with the quality and criteria they need. A company that sells its products directly to consumers and through distribution makes different pricing. As for promotions, the product's price will be lower if the cost of product promotion is not only borne by the company, but also by the retailers. An entrepreneur needs to consider the production cost and the changes that occur in the quantity of production if he wants to set an effective price. Tjiptono (2001) argued that price is often a value's indicator when the indicator is associated with the perceived benefits of goods or services. Hence, it is able to be inferred that at a specific level of price, if the advantages experienced by purchasers improve, the value will also improve, and this can increase the competitiveness of the products offered.

H3: There is a positive influence of price on the level of product success

\subsection{The Impact of Product Success Rate on the Business Performance}

The innovation of product is progressively esteemed as a key part of continuous achievement in the business process. Firman, Putra, Mustapa, Ilyas, and Karim (2020), Henard and Szymanski (2001), in their research, said that product excellence, market potential, meeting customer needs, pre-development of job skills, and resource use, in general, are mostly those that have a significant impact on the performance of new products. According to Samu, Krishnan, and Smith (1999), the attributes or characteristics of new products sold in the market will determine the level of success of these products. The consumer's decision to repurchase the product is a form of success for the new product. The components, attributes, and characteristics of the product are essential things that must be considered to improve its market performance. One of the indications of a product's success or failure is consumer buying interest (how much interest someone has to buy a product). It can be said that this interest will lead to the frequency of purchase or repurchase; therefore, the dimension of purchase interest is the amount of interest or how likely the purchase is going to be (Mittal, 2002).

H4: There is a positive influence on the level of product success on business performance

\section{Research Methods}

This research utilized quantitative data types in light of the fact that the data introduced were identified with numbers or scoring. Then, the data was scrutinized and processed into statistical analysis to examine the hypotheses that clarified the connection between the variables utilized. The data source employed in this investigation was the primary data. The endogenous variable in this research was the success rate of product and the performance of SMEs. 2. Exogenous Variable $(\mathrm{X})$. Exogenous variable is a variable that will influence the endogenous variable, or as such, the exogenous variable is the reason for the arrangement of the endogenous variable. The exogenous factors utilized in this study were the characteristics of product, market competitive strategy, and price. The population in this study were all SMEs in West Java. The example employed was Batik SMEs in Cirebon with at least ten years in business, and the number of Batik SMEs in Cirebon was 165. 


\section{Result and Discussion}

In light of the data gathered during the research, a questionnaire conveyed to respondents with 165 duplicates. Most of the respondents were female (110) and the age group which gavel the most number of responses was between 41 to 50 with 65 individuals. Table 1 underneath shows the existing data analysis results (see Table 1).

Reliability is a proportion of inward consistency of the indicators of an arrangement variable that indicates how much every indicator demonstrates a typical development variable. There are two different ways to test reliability, to be specific by composite/develop reliability and variance extracted. The cut-off value of the stability reliability is at least 0.70 , while the cut-off value for the extracted variance is in any event 0.50 . Variance extracted shows the amount of variance of the indicator extracted from the framed variable created. High variance extracted values indicate that the indicators are well represented by the formed variables that were developed (see Table 2).

Based on Table 2, reliability for each construct ended up being high, and all values were over the cut-off value of 0.70 .
The calculated variance demonstrated that all constructs met the base cut-off value requirement of 0.50 (see Table 2).

Based on Table 3, the results of testing can be concluded that product characteristics had a positive effect on product success rate. The market competitive strategy had a positive effect on product success rate. Price had a positive effect on product success rate. At last, the product success rate had a positive effect on SMEs' performance. All four hypotheses were accepted so that the success of the existing products at the SMEs of Batik amid the COVID-19 pandemic was influenced by product characteristics, market competitive strategies, and price. Even though the market share is declining in this pandemic condition, if Batik SMEs in Cirebon pay attention to these three exogenous variables, it will improve their business performance.

Besides, from in-depth interviews, it is known that the factors that influenced the success of an SME were the same for each type of business. However, what distinguishes each UKM was the magnitude of the problems they might face. SMEs that have raw materials or are directly related to materials with relatively unstable prices, such as staples, fuel, and others, indicate that they will experience a more difficult problem than

Table 1: Sample Characteristics

\begin{tabular}{|l|c|c|c|}
\hline \multicolumn{2}{|c|}{ Demographics Characteristics } & Number of Response & Percentage (\%) \\
\hline \multirow{4}{*}{ Age } & $<30$ & 35 & 21 \\
\cline { 2 - 4 } & $31-40$ & 30 & 19 \\
\cline { 2 - 4 } & $41-50$ & 65 & 39 \\
\cline { 2 - 4 } & $>51$ & 35 & 21 \\
\hline \multirow{2}{*}{ Gender } & Male & 55 & 33 \\
\cline { 2 - 4 } & Female & 110 & 67 \\
\hline
\end{tabular}

Table 2: Reliability and Variance Extracted Test

\begin{tabular}{|l|c|c|}
\hline Variable & Reliability & AVE \\
\hline Product Characteristics & 0.883 & 0.654 \\
\hline Market competitive strategy & 0.852 & 0.69 \\
\hline Price & 0.909 & 0.715 \\
\hline Product success rate & 0.91 & 0.67 \\
\hline Performance of SMEs & 0.93 & 0.725 \\
\hline
\end{tabular}

Table 3: Hypothesis Testing

\begin{tabular}{|l|c|c|c|c|}
\hline Variable & Estimate & SE & CR & P \\
\hline Product Characteristics $\rightarrow$ Product success rate & 0.147 & 0.108 & 2.108 & 0.029 \\
\hline Market competitive strategy $\rightarrow$ Product success rate & 0.162 & 0.125 & 2.781 & 0.014 \\
\hline Price $\rightarrow$ Product success rate & 0.175 & 0.154 & 2.848 & 0.010 \\
\hline Product success rate $\rightarrow$ SMEs Performance & 0.389 & 0.167 & 2.906 & 0.008 \\
\hline
\end{tabular}


other types of SMEs. Nevertheless, it does not mean they do not have a chance to succeed. They will become more successful if they manage their strategies well and are not fixated by the problems they face. From the results of in-depth interviews, it is known that actually many SMEs face this problem, but they still succeed because they have a pretty good network marketing system and can keep up with the times.

\section{Conclusion}

This study aimed to examine the effect of product characteristics, market competitive strategy, price and product success rate on the success of performance of SME. SMEs are expected to be able to process the success of their products for their businesses. Besides, SMEs can produce different product characteristics to avoid product monotony and carry out competitive market and price strategies in their business, especially during the COVID-19 pandemic. Prices become very sensitive in buying and selling activities. SMEs are expected to explore the uniqueness of their products, improve the quality of their products, and apply competitive prices to create healthy competition in the market.

Judging from the characteristics of SMEs, it can be concluded that all the variables product characteristics, market competition strategies, and prices were significant factors for success of an SME and could improve SMEs' performance. Judging from the contextual variables, it can be concluded that the dimensions of SME performance were strongly positively related to the level of product success. SMEs that are easy to maintain in terms of product, market, and price characteristics are likely to be more successful. Meanwhile, SMEs have difficulty maintaining the characteristics of the product, market, and the price will be less successful. For SMEs, product success is the most critical thing as drivers of their success, meaning that a good performance of SMEs is identical to the success of their products.

\section{References}

Becker, K., Lee, J. W., \& Nobre, H. M. (2018). The Concept of Luxury Brands and the Relationship between Consumer and Luxury Brands. Journal of Asian Finance, Economics and Business, 5(3), 51-63. http://doi.org/10.13106/jafeb.2018.vol5. no3.51

Beal, R. M. (2000). Competing effectively: Environmental scanning, competitive strategy, and organizational performance in small manufacturing firms. Journal of Small Business Management, 38(1), 27-47.

Bell, D. (1976). The coming of the post-industrial society. In: The Educational Forum (Vol. 40, No. 4, pp. 574-579). New York, NY: Taylor \& Francis Group.

Conner, K. R. (1991). A historical comparison of resourcebased theory and five schools of thought within industrial organization economics: Do we have a new theory of the firm?. Journal of Management, 17(1), 121-154. https://doi. org/10.1177/014920639101700109

Cooper, R. G. (1992). The New Product System: The Industry Experience. Journal of Product Innovation Management, 9(2), 113-27.

Delene, L. M., Meloche, M. S., \& Hodskins, J. S. (1997). International product strategy: building the standardisationmodification decision. Irish Marketing Review, 10(1), 47-54.

Doyle, P., \& Wong, V. (1998). Marketing and competitive performance: an empirical study.EuropeanJournalofMarketing, 32(5/6), 514-535. https://doi.org/10.1108/03090569810216145

Firman, A., Putra, A. H. P. K., Mustapa, Z., Ilyas, G. B., \& Karim, K. (2020). Re-conceptualization of Business Model for Marketing Nowadays: Theory and Implications. Journal of Asian Finance, Economics and Business, 7(7), 279-291. https:// doi.org/10.13106/jafeb.2020.vol7.no7.279

Gupta, A. K., Raj, S. P., \& Wilemon, D. (1985). The R\&Dmarketing interface in high-technology firms. Journal of Product Innovation Management, 2(1), 12-24. https://doi. org/10.1016/0737-6782(85)90012-8

Henard, D. H., \& Szymanski, D. M. (2001). Why some new products are more successful than others. Journal of Marketing Research, 38(3), 362-375. https://doi.org/10.1509/jmkr.38.3.362.18861

Hunt, S. D., \& Morgan, R. M. (1995). The comparative advantage theory of competition. Journal of Marketing, 59(2), 1-15. https://doi.org/10.1177/002224299505900201

Jaworski, B., Kohli, A. K., \& Sahay, A. (2000). Market-driven versus driving markets. Journal of the Academy of Marketing Science, 28(1), 45-54. https://doi.org/10.1177/0092070300281005

Jeaning, P., \& Beaver, G. (1997). The Performance and Competitive Advantage of Small Firms. A management perspective. International Small Business Journal, 15(2), 63-75.

Keats, B. W., \& Hitt, M. A. (1988) A Causal Model of Linkages among Environmental Dimensions, Macro Organizational Characteristics, and Performance. The Academy of Management Journal, 31(3), 570-598.

Kim, C. W., \& Mauborgne, R. (2005). Value innovation: a leap into the blue ocean. Journal of Business Strategy,26(4), 22-28. https://doi.org/10.1108/02756660510608521

Kotler, P., \& Armstrong, G. (2006). Marketing (vol. 10). Upper Saddle River, NJ: Prentice Hall.

Lestari, S. D., Leon, F. M., Widyastuti, S., Brabo, N. A., \& Putra, A. H. P. K. (2020). Antecedents and Consequences of Innovation and Business Strategy on Performance and Competitive Advantage of SMEs. Journal of Asian Finance, Economics and Business, 7(6), 365-378. https://doi.org/10.13106/jafeb.2020. vol7.no6.365

Li, T., \& Calantone, R. J. (1998). The impact of market knowledge competence on new product advantage: conceptualization and empirical examination. Journal of Marketing, 62(4), 13-29. https://doi.org/10.1177/002224299806200402 
Mittal, B. (2002). Services communications: from mindless tangibilization to meaningful messages. Journal of Services Marketing, 16(5), 424-431. https://doi. org/10.1108/08876040210436894

Muafi, M. (2020). A Nexus among Strategic Orientation, Social Network, Knowledge Sharing, Organizational Innovation, and MSMEs Performance. Journal of Asian Finance, Economics and Business, 7(6), 327-338. https://doi.org/10.13106/ jafeb.2020.vol7.no6.327

Prahalad, C. K., \& Hamel, G. (1997). The core competence of the corporation. In Strategic business planning/ strategic business management. In: Physica (pp. 969-987). Heidelberg, Germany: Springer. https://link.springer.com/ chapter/10.1007/978-3-662-41482-8_46

Samu, S., Krishnan, H. S., \& Smith, R. E. (1999). Using advertising alliances for new product introduction: interactions between product complementarity and promotional strategies. Journal of Marketing, 63(1), 57-74. https://doi.org/10.1177/00222429 9906300105.
Sinkula, J. M. (1994). Market information processing and organizational learning. Journal of Marketing, 58(1), 35-45. https://doi.org/10.1177/002224299405800103

Song, X. M., \& Parry, M. E. (1997). The determinants of Japanese new product successes. Journal of Marketing Research, 34(1), 64-76. https://doi.org/10.1177/002224379703400106

Tjiptono, F. (2001). Marketing strategy. Yogyakarta, Indonesia: Andi Publisher. [Indonesian]

Voss, G. B., \& Voss, Z. G. (2000). Strategic orientation and firm performance in an artistic environment. Journal of Marketing, 64(1), 67-83.

Yuniawan, A., Harjadi, D., Filatrovi, E. W., Dananjoyo, R., \& Arraniri, I. (2020). Testing the Relationships between Human Resource Competence, Financial Aspect and SMEs Performance. Journal of Talent Development and Excellence, 12(2s), 2295-2303. http://www.iratde.com/index.php/jtde/ article/view/943

Zahra, S. A., \& Das, S. R. (1993). Innovation strategy and financial performance in manufacturing companies: An empirical study. Production and Operations Management, 2(1), 15-37. https:// doi.org/10.1111/j.1937-5956.1993.tb00036.x 